\title{
Antiatherogenic Effect of Losartan in the Hyperlipidemic Rat
}

\author{
Sultana $\mathrm{R}^{1}$, Rahman $\mathrm{S}^{2}$, Banu LA 3 , Any $\mathrm{OH}^{4}$
}

\begin{abstract}
Background: Angiotensin II is a powerful growth stimulant that can lead to smooth muscle hyperplasia in vascular wall. Objectives: The present study was aimed to find out the anti-atherosclerotic effects of angiotensin II receptor blocker losartan. Methodology: This experimental animal study was carried out in the Laboratory of the Department of Pharmacology \& Therapeutics at Banghabandhu Sheik Mujib Medical University (BSMMU) Dhaka from July 2008 to June 2009. Healthy Long-Evans Norwegian male rats aged between 3-4 months with an weight of 180 to 200 gm were randomly selected and were divided into 3 groups designated as group A, B and C. Group A was fed on standard rat diet; group B was fed soybean oil and group $\mathrm{C}$ was fed a $2 \%$ cholesterol enriched diet which was the suspension of cholesterol powder in soybean oil. After 8 weeks 10 rats of each group were sacrificed and remaining 20 rats of group C were continued to the part II of the experiment and divided into two groups known as group I which was cholesterol fed control group and group II which were losartan treated group. After 8 weeks all the rats of two groups were sacrificed. Blood from each rat was collected to measure the lipid profile and malondialdehyde (MDA) level within erythrocyte. The aorta was separated and intima-media ratio was measured by using Image-pro plus software. Results: Losartan induces a significant reduction in serum lipids $(\mathrm{p}<0.001)$ and in atherosclerotic lesion size $(\mathrm{p}<0.001)$. It also significantly reduces the oxidative stress by reduction of malondialdehyde (MDA) level $(\mathrm{p}<0.001)$. Conclusions: In a atherosclerosis rat model, losartan reduces the oxidative stress and the neointimal inflammation and this could due to direct inhibition of angiotensin II in the arterial wall. [J Shaheed Suhrawardy Med Coll, 2013;5(2):99-102]
\end{abstract}

Keywords: Cholesterol, atherosclerosis, angiotensin II, losartan

Received: March 2013; Revised: July 2013; Accepted: August 2013

\section{Introduction}

Atherosclerosis related disease is the leading cause of death and disability in the world ${ }^{1}$. Hypercholesterolemia and angiotensin II involve in atherogenesis ${ }^{2-3}$. Angiotensin II is a powerful growth stimulant that can causes smooth muscle hyperplasia in the vascular wall ${ }^{4-8}$. Angiotensin II is the main effectors of rennin-angiotensin system and mediates the most of the biological effects of this system ${ }^{9-10}$. Angiotensin II and the AT1 receptor play a role in atherogenic process by endothelial dysfunction, superoxide anion generation, inflammatory cytokines formation and impaired fibrinolysis ${ }^{9-10}$. Angiotensin II also stimulates macrophage lipid peroxidation and can lead to cell-mediated oxidation of LDL and the formation of atherogenic oxidized $\mathrm{LDL}^{11}$. by inhibition of lipid peroxidation of LDL cholesterol and improvement of endothelial function by angiotensin II receptor blocker, losartan, may have an important role contributing to attenuation of atherogenic process independent of lowering of blood pressure ${ }^{12-17}$.

Experimental evidence suggests that losartan not only block the effects of angiotensin II on AT1 receptor through both ACE-dependent and ACE-independent (chymase-mediated) pathway, but also stimulates the anti-atherosclerotic AT2

1. Dr. Rezina Sultana, Assistant Professor, Department of Pharmacology, Z. H. Sikder Women's Medical College, Dhaka

2. Prof. Dr. Sayedur Rahman, Professor, Department of Pharmacology \& Therapeutics, Banghabandhu Sheik Mujib Medical University, Dhaka.

3. Prof. Dr. Layla Afroza Banu, Professor \& Head, Department of Pharmacology \& Therapeutics, Shaheed Suhrawardy Medical College, Dhaka.

3. Dr. Omma Hafsa Any, Assistant Professor, Department of Pharmacology, Z. H. Sikder Women's Medical College, Dhaka.

\section{Correspondence}

Dr. Rezina Sultana, Assistant Professor, Department of Pharmacology, Z. H. Sikder Women's Medical College, Dhanmondi, Dhaka-1207, Bangladesh; E-mail: rsultana401@gmail.com Mobile:+8801711908588

Funding Source: This study was supported by the fund of Department of Pharmacology, Banghabandhu Sheik Mujib Medical University, Shahbag, Dhaka. Conflict of interest: None

Contributions by authors: RS: Conduct all sorts of laboratory and analysis job like, timely fed the rates, collect serum for lab testing, collect aorta for histopathological examinations, data analysis by SPSS and intima media ratio done by using image proplus software. SR: Supervise the whole work and timely give the suggestions. LAB \& OHA: Revised the manuscript 
receptor ${ }^{18}$. So, losartan appears to be a better alternative to ACE-inhibitors for treating atherosclerosis and dyslipidemia in hypertensive patients ${ }^{19}$. Therefore, the present study was aimed to find out the anti-atherosclerotic effects of angiotensin II receptor blocker losartan.

\section{Methodology}

This experimental animal study was carried out in the Laboratory of the Department of Pharmacology \& Therapeutics at Banghabandhu Sheik Mujib Medical University (BSMMU), Dhaka from 1st July 2008 to 30th June 2009 for a period of 1(one) year. Healthy Long-Evans Norwegian male rats aged between 3-4 months and weighing between 180-200 gm were randomly selected and were divided into 3 groups designated as group A, B and C. Group A were fed on standard rat diet for 8 weeks which was taken as control; group B (vehicle fed) were fed soybean oil at a dose of $1 \mathrm{ml}$ once daily for 8 weeks and group C ( $2 \%$ cholesterol fed) were fed a $2 \%$ cholesterol enriched diet which was prepared by the suspension of cholesterol powder in soybean oil at a dose of $100 \mathrm{mg} / \mathrm{ml}$ of $2 \mathrm{ml}$ once daily for 8 weeks. After 8 weeks 10 rats of each group were sacrificed and remaining 20 rats of group $\mathrm{C}$ were continued to the part II of the experiment and divided into two groups known as group I and group II. Group-I was fed $0.5 \mathrm{ml}$ of $0.1 \%$ cholesterol-enriched diet once daily to maintain atherosclerotic state designated as the cholesterol fed control group and Group-II were treated with $0.5 \mathrm{ml}$ of $10 \mathrm{mg} / \mathrm{ml}$ Losartan at a dose of 25 $\mathrm{mg} / \mathrm{Kg}$ /day along with $0.5 \mathrm{ml}$ of $0.1 \%$ cholesterol enriched diet designated as the Losartan treated group. After 8 weeks all the rats of two groups were sacrificed under anesthesia with chloroform. Blood from each rat was collected from carotid artery and then preparation of serum for estimation of lipid profile by enzymatic method and separation of erythrocyte and preparation of erythrocyte hemolysate for estimation erythrocyte malondialdehyde $(\mathrm{MDA})^{20}$. The aorta was separated from the surrounding viscera, inner thoracic wall and abdominal wall and was dissected out to preserve for histopathological examination $^{21}$. Morphological study of the aorta was done under microscope after preparation and staining of the aortic tissue slide ${ }^{22}$. Intima-media ratio was measured by using Image-pro plus software ${ }^{21}$. All the quantitative data obtained from the experiments have been expressed as mean \pm standard deviation (mean \pm SD). One-way analysis of variance (ANOVA) followed by Bonferroni test was used for comparisons between groups. Statistical significance was accepted at the level of $5 \%(p<0.05)$. Statistical analysis was performed using SPSS software version 16 for windows.

\section{Results}

Part-I of the experiment was carried out to determine the effect of 8 weeks feeding of $2.0 \%$ cholesterol diet on the lipid profile (Table 1), oxidative stress in erythrocyte (Table 2) \& morphology of aortic tissue (Table 3 ) of rat.
Table 1: Effect of $2.0 \%$ cholesterol feeding for 8 weeks on lipid profile of rats

\begin{tabular}{lcccc}
\hline Variable & \multicolumn{3}{c}{ Groups (n=30) } & \\
\cline { 2 - 4 } & $\begin{array}{c}\text { Group A } \\
(\mathrm{n}=10)\end{array}$ & $\begin{array}{c}\text { Group B } \\
(\mathrm{n}=10)\end{array}$ & $\begin{array}{c}\text { Group C } \\
(\mathrm{n}=10)\end{array}$ & P value \\
\hline Cholesterol & $77.66 \pm 1.09$ & $78.90 \pm 1.21$ & $186.42 \pm 3.13^{* *}$ & $<0.001^{*}$ \\
Triglycerides & $65.31 \pm 0.98$ & $65.23 \pm 1.13$ & $130.70 \pm 2.26^{* *}$ & $<0.001^{*}$ \\
HDL & $45.38 \pm 0.73$ & $45.13 \pm 0.90$ & $34.32 \pm 1.06^{* *}$ & $<0.001^{*}$ \\
LDL & $19.06 \pm 1.54$ & $20.73 \pm 1.35$ & $125.96 \pm 4.23^{* *}$ & $<0.001^{*}$ \\
LDL-HDL ratio & $0.41 \pm 0.03$ & $0.45 \pm 0.03$ & $3.48 \pm 0.16^{* *}$ & $<0.001^{*}$
\end{tabular}

* LDL= Low Density lipoprotein; HDL= High Density lipoprotein, all values are in $\mathrm{mg} / \mathrm{dl}$

Part-II of the experiment was carried out to determine the effects of 8 weeks feeding of $2.0 \%$ cholesterol diet followed by another 8 weeks feeding of $0.1 \%$ cholesterol diet with losartan treatment on the lipid profile (Table 4), oxidative stress in erythrocyte (Table 5) \& morphology of aortic tissue (Table 6) of rat.

Table 2: Effect of $2.0 \%$ cholesterol feeding for 8 weeks on malondialdehyde (MDA) levels in erythrocyte of rats

\begin{tabular}{lcc}
\hline Groups & $\begin{array}{c}\text { Erythrocyte MDA } \\
\text { Mean } \pm \text { SD }\end{array}$ & p value \\
\hline Group A $(n=10)$ & $7.26 \pm 0.25$ & \\
Group B $(n=10)$ & $7.41 \pm 0.35$ & $<0.001^{*}$ \\
Group C $(n=10)$ & $13.35 \pm 0.25^{* *}$ & \\
\hline
\end{tabular}

* F value $=1400.89 ; \mathrm{MDA}=$ malondialdehyde

In experiment-I there was marked increase in serum cholesterol, triglycerides \& LDL-cholesterol level, LDLHDL ratio and malondialdehyde (MDA) level in erythrocyte $(\mathrm{RBC})$ \& intima-media ratio of aorta in the $2.0 \%$ cholesterol fed group (C) as compared to control group A and soybean oil fed group $\mathrm{B}$ and the rise was statistically significant $(\mathrm{p}<0.001)$.

Table 3: Effect of $2.0 \%$ cholesterol feeding for 8 weeks on morphology of aortic tissue of rats

\begin{tabular}{lccccc}
\hline Variable & \multicolumn{5}{c}{ Groups $(\mathrm{n}=30)$} \\
\cline { 2 - 6 } & $\begin{array}{c}\text { Group A } \\
(\mathrm{n}=10)\end{array}$ & $\begin{array}{c}\text { Group B } \\
(\mathrm{n}=10)\end{array}$ & $\begin{array}{c}\text { Group C } \\
(\mathrm{n}=10)\end{array}$ & F value & P value \\
\hline $\begin{array}{l}\text { intima-media } \\
\text { ratio of aorta }\end{array}$ & $0.52 \pm 0.01$ & $0.54 \pm 0.01$ & $2.15 \pm 0.04^{* *}$ & 11874.45 & $<0.001^{*}$ \\
\hline
\end{tabular}

Table 4: Effect of Losartan treatment on serum lipid profile of $2.0 \%$ cholesterol fed rats

\begin{tabular}{llll}
\hline Variable & Group I $(\mathbf{n = 1 0})$ & Group II $(\mathbf{n = 1 0})$ & P value \\
\hline Cholesterol & $123.93 \pm 1.53$ & $102.62 \pm 2.00^{* *}$ & $<0.001^{*}$ \\
Triglycerides & $112.28 \pm 2.56$ & $102.62 \pm 3.05^{* *}$ & $<0.001^{*}$ \\
HDL & $37.14 \pm 1.06$ & $41.36 \pm 1.06^{* *}$ & $<0.001^{*}$ \\
LDL & $64.43 \pm 2.26$ & $40.73 \pm 2.03^{* *}$ & $<0.001^{*}$ \\
LDL-HDL ratio & $1.73 \pm 0.10$ & $0.98 \pm 0.05^{* *}$ & $<0.001^{*}$ \\
\hline
\end{tabular}

* LDL $=$ Low Density lipoprotein; HDL= High Density lipoprotein 
In experiment-II there were marked decrease in serum cholesterol, triglycerides, LDL-cholesterol, LDL-HDL ratio, malondialdehyde (MDA) level in erythrocyte (RBC) \& intima-media ratio of aorta in losartan treated group-II as compared to cholesterol fed control group-I and the change were statistically highly significant $(\mathrm{P}<0.001)$.

Table 5: Effect of Losartan treatment on malondialdehyde (MDA) levels in erythrocyte of $\mathbf{2 . 0 \%}$ cholesterol fed rats

\begin{tabular}{lcc}
\hline Group II & Mean \pm SD & P value \\
\hline Group I & $12.77 \pm 0.20$ & \\
Group II & $10.07 \pm 0.18$ & $<0.001$ \\
\hline
\end{tabular}

* Student $\mathrm{t}$ test was performed to see the association

Histopathological Examination: Histopathological Examination of thoracic aorta specimen of $2.0 \%$ cholesterol fed rats under microscope showing narrowing of the lumen of aorta due to gross atherosclerotic plaque in sub endothelial region. There were foam cells, inflammatory cells and fat leaden smooth muscle cells found in sub endothelial region. Middle layer (Media) of the aorta was thin (Figur-1). After losartan treatment there were no foam cells, inflammatory cells and fat leaden smooth muscle cells in sub endothelial region of aorta. Increased thickness of the middle layers of the aorta. The intima and media region are resembling near normal (Figur-2).

Table 6: Effect of Losartan treatment on morphology of aortic tissue of $2.0 \%$ cholesterol fed rats

\begin{tabular}{lrc}
\hline Group & Mean \pm SD & P value \\
\hline Group I & $2.29 \pm 0.02$ & \\
Group II & $1.79 \pm 0.03$ & $<0.001$ \\
\hline
\end{tabular}

* Student $t$ test was performed to see the association

\section{Discussion}

The present study showed that losartan decreases serum cholesterol, triglyceride, LDL-c and increases HDL-c level, which resembles to the findings of few other studies ${ }^{23-24}$. Hypolipidaemic benefit of losartan in this study might be due to its ability to decrease plasma lipoprotein and fibrinogen level ${ }^{25}$.

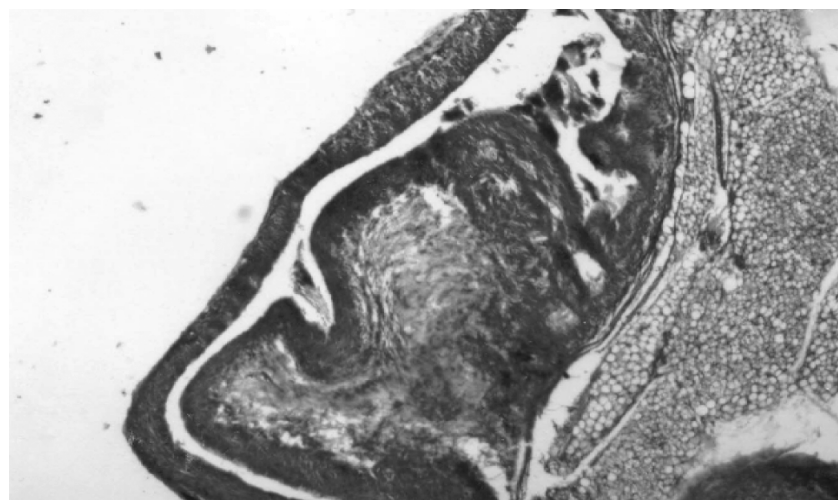

Figure 1: Photomicrograph showing histological cross-section of thoracic aorta specimen of rat fed a $2.0 \%$ cholesterol-enriched diet for 8 weeks. Magnification (X10)
The present study was also revealed that losartan exerted antioxidant effect by decreasing malondialdehyde (MDA) levels in erythrocyte which is similar to the findings to other studies ${ }^{26-28}$ and these effects might be due to its blocking effect on the angiotensin II mediated oxidative stress through its action on angiotensin type 1 receptor which is involved in producing superoxide anion, endothelial dysfunction and lipid peroxidation.

The morphological study of aortic tissue was revealed the anti-atherosclerotic effect of losartan. This might be due to its decreasing effect on vascular smooth muscle cell migration, proliferation and extracellular matrix production, decrease the release of plasminogen activator inhibitor-1 from vascular smooth muscle cells, reduce the expression of monocyte chemoattractant protein-1 in vascular smooth muscle cells; decrease the expression of adhesion proteins, such as intercellular adhesion molecule-1, integrins and osteopontin in vascular cells ${ }^{29}$ and decrease the production of inflammatory chemokines and cytokines that enhance the migration of inflammatory cells $\mathrm{s}^{30}$.

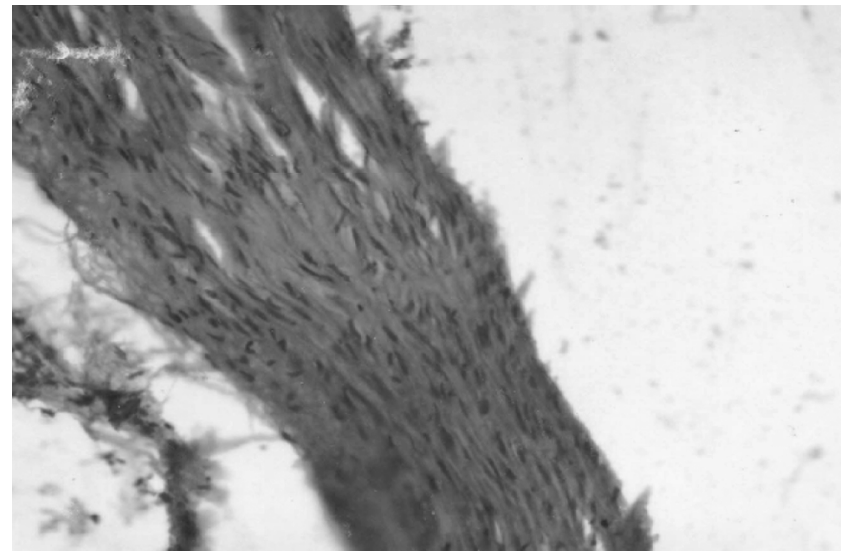

Figure 2: Photomicrograph showing histological cross-section of thoracic aorta specimen of rat fed $2.0 \%$ cholesterol diet for 8 weeks then treated with Losartan for another 8 weeks. Magnification (X10)

In this study the histopathological examination of aorta revealed that there were decrease foam cells, inflammatory cells and fat leaden smooth muscle cell in sub-endothelial region and increase the thickness of middle layer of aorta which might be due to its decreasing effect on vascular smooth muscle cell migration, proliferation and extracellular matrix production ${ }^{29}$, decrease production of inflammatory cytokines and chemokines that enhance the migration of inflammatory cells ${ }^{30}$.

\section{Conclusion}

In conclusion the anti-atherosclerotic effects of losartan in cholesterol fed rat are due to a direct inhibition of angiotensin II actions in the arterial wall, including inhibition of LDL lipid peroxidation.

\section{References}

1. Chopra V, Wasir HS. Implications of lipoprotein abnormalities in Indian patients. JAPI 1998; 46: 814-18.

2. Keider S, Kaplan M, Hoffman A, Aviram M. Angiotenism II stimulates macrophage-mediated lipid peroxidation of LDL. Atherosclerosis 1995; 115:201-215. 
3. Keider S, Kaplan M. Angiotensin II-modified LDL is taken up by macrophages via the scavenger receptor leading to cellular cholesterol accumulation. Arterioscler Vasc Biol 1996;16:97-105.

4. Geisterfer A, Peach M, Owens G. Angiotensin II induces hypertrophy of cultured rat aortic smooth muscle cells. Circ Res 1988;62:749-756.

5. Campbell-Boswell M, Robertson A. Effects of angiotensin II and vasopressin on human smooth muscle cells in vitro. Exp Mol Pathol 1981;35:265-273.

6. Daemon M, Lombardi D, Bosman F, Schwartz S. Angiotensin II induces smooth muscle cell proliferation in the normal and injured rat arterial wall. Circ Res 1991;68:450-456.

7. Wolf G, Haberstroh U, Neilson E. Angiotensin II stimulates the proliferation and biosynthesis of type-I collagen in cultured murine mesangial cells. Am J Pathol 1992;140:95-107.

8. Katoh H, Suzuki H, Ogata Y. Angiotensin II stimulates collagen and fibronectin synthesis in cultured vascular smooth muscle cells. Clin Exp Hyperten 1990;12:675-688.

9. Strehlow K, Wassmann S, Bohm M, Nickenig G. Angiotensin AT1 receptor over-expression in hypercholesterolaemia. Ann Med. 2000; 32: 386-9.

10. Weiss D, Kools JJ, Taylor WR. Angiotensin II-induced hypertension accelerates the development of atherosclerosis in ApoE-deficient mice. Circulation 2001; 103: 448-54.

11. Keidar S, Kaplan M, Hoffman A, Aviram M. Angiotensin II stimulates macrophage-mediated oxidation of low density lipoproteins. Atherosclerosis 1995; 115: 201-15.

12. Yui S, Sasaki T, Miyazaki A, Horiuchi S, Yamazaki M. Induction of murine macrophage growth by modified LDLs. Arterioscler Thromb. 1993; 13: 331-37.

13. Griendling KK, Minieri CA, Ollerenshaw JD, Alexander RW. Angiotensin II stimulates NADH and NADPH oxidase activity in cultured vascular smooth muscle cells. Circ Res. 1994; 74: 1141-8.

14. Mohazzab KM, Kaminski PM, Wolin MS. NADH oxidoreductase is a major source of superoxide anion in bovine coronary artery endothelium. Am J Physiol 1994; 266: H2568-72.

15. Hayek T, Attias J, Coleman R, Brodsky S, Smith J, Breslow JL, et al. The angiotensin-converting enzyme inhibitor, fosinopril, and the angiotensin II receptor antagonist, Losartan, inhibit LDL oxidation and attenuate atherosclerosis independent of lowering blood pressure in apolipoprotein $\mathrm{E}$ deficient mice. Cardiovasc Res 1999; 44: 579-87.

16. Koh KK, Ahn JY, Han SH, Kim DS, Jin DK, Kim HS, et al. Pleiotropic effects of angiotensin II receptor blocker in hypertensive patients. J Am Coll Cardiol 2003; 42: 905-10.

17. Prasad A, Tupas-Habib T, Schenke WH, Mincemoyer R, Panza JA, Waclawin $\mathrm{MA}$, et al. Acute and chronic angiotensin-1 receptor antagonism reverses endothelial dysfunction in atherosclerosis. Circulation 2000; 101: 2349-54.

18. Okunishi H, Oka Y, Shiota N, Kawamoto T, Song K, Miyazaki M.
Marked species-difference in the vascular angiotensin II-forming pathways: humans versus rodents. Jpn J Pharmacol 1993; 62: 207-10.

19. Sonoda M, Aoyagi T, Takenaka K, Uno K, Nagai R. A one-year study of the antiatherosclerotic effect of the angiotensin-ii receptor blocker Losartan in hypertensive patients: a comparison with angiotensin-converting enzyme inhibitors. Int Heart J 2008; 49: 95-103.

20. Shivarajashankara YM, Shivashankara AR, Rao SH, Bhat PG. Oxidative stress in children with endemic skeletal flurosis. Fluoride 2001; 34: 103-07.

21. Silva EP, Fonseca FA, Ihara SS, Izar MC, Lopes IL, Pinto LE, et al. Early benefits of pravastatin to experimentally induced atherosclerosis. J Cardiovasc Pharmacol 2002; 39: 389-95.

22. Stary HC, Chandler AB, Dinsmore RE, Fuster V, Glagov S, Insull W Jr, et al. A definition of advanced types of atherosclerotic lesions and a histological classification of atherosclerosis. A report from the committee on vascular lesions of the council on arteriosclerosis, American Heart Association. Circulation 1995; 92: 1355-74.

23. Imanishi T, Kuroi A, Ikejima H, Kobayashi K, Muragaki Y, Mochizuki S, et al. Effects of angiotensin converting enzyme inhibitor and angiotensin II receptor antagonist combination on nitric oxide bioavailability and atherosclerotic change in Watanabe heritable hyperlipidemic rabbits. Hypertens Res 2008; 31: 575-84.

24. Koh KK, Quon MJ, Han SH, Chung WJ, Ahn JY, Seo YH, et al. Additive Beneficial Effects of Losartan Combined With Simvastatin in the Treatment of Hypercholesterolemic, Hypertensive Patients. Circulation 2004; 110: 3687-92.

25. Papadakis JA, Ganotakis ES, Jagroop IA, Mikhailidis DP, Winder AF. Effect of hypertension and its treatment on lipid, lipoprotein(a), fibrinogen, and bilirubin levels in patients referred for dyslipidemia. Am J Hypertens 1999; $12: 673-81$.

26. Hayek T, Aviram M, Heinrich R, Sakhnini E, Keidar S. Losartan inhibits cellular uptake of oxidized LDL by monocyte-macrophages from hypercholesterolemic patients. Biochem Biophys Res Commun 2000; 273: 417-20. 27. Polizio AH, Peña C. Effects of angiotensin II type 1 receptor blockade on the oxidative stress in spontaneously hypertensive rat tissues. Regul Pept 2005; 128: 1-5.

28. Yao EH, Fukuda N, Matsumoto T, Kobayashi N, Katakawa M, Yamamoto C, et al. Losartan improves the impaired function of endothelial progenitor cells in hypertension via an antioxidant effect. Hypertens Res 2007; 30: 1119-28.

29. Pastore L, Tessitore A, Martinotti S, Toniato E, Alesse E, Bravi MC, et al. Angiotensin II stimulates intercellular adhesion molecule-1 (ICAM-1) expression by human vascular endothelial cells and increases soluble ICAM1 release in vivo. Circulation 1999; 100: 1646-52.

30. Ruiz-Ortego M, Lorenzo O, Ruperez M, Esteban V, Suzuki Y, Mezzano $\mathrm{S}$, et al. Role of the renin-angiotensin system in vascular diseases: Expanding the field. Hypertension 2001; 38: 1382-87 